This manuscript is a preprint and has been submitted to Nature Communications. Please note that the manuscript is currently undergoing peer-review and has therefore not yet been accepted for publication. Subsequent versions of this manuscript may have slightly different content.

If accepted, the final version of this manuscript will be available via the 'Peer-reviewed Publication DOI' link on the right-hand side of this webpage. Please feel free to contact any of the authors; we welcome feedback 


\section{Iron oxide reactivity controls organic matter mineralization in ferruginous sediments}

André Friese1†, Kohen Bauer2†, Clemens Glombitza3,4, Luis Ordoñez5, Daniel Arizteguis, Verena B. Heuer6, Aurèle Vuillemin1,7, Cynthia Henny8, Sulung Nomosatryo1,8, Rachel Simister4, Dirk Wagner1,9, Satria Bijaksana10, Hendrik Vogel11, Martin Melles12, James M. Russell13, Sean A. Crowe2*, Jens Kallmeyer1*, and the Towuti Drilling Project Science Team13

„GFZ German Research Centre for Geosciences, Section 3.7 Geomicrobiology, D-14473 Potsdam, Germany ${ }_{2}$ Department of Microbiology and Immunology and Department of Earth, Ocean, and Atmospheric Sciences, University of British Columbia, Vancouver, Canada

з ETH Zürich, Institute of Biogeochemistry and Pollutant Dynamics, Universitätstrasse 16, 8092 Zürich, Switzerland

${ }_{4}$ Center for Geomicrobiology, Aarhus University, Aarhus, Denmark

${ }_{5}$ Department of Earth Sciences, University of Geneva, rue des Maraichers 13, 1205 Geneva, Switzerland ${ }_{6}$ MARUM - Center for Marine Environmental Sciences, University of Bremen, Leobener Straße 8, D-28359 Bremen, Germany

7Ludwig-Maximilians-Universität München, Department of Earth \& Environmental Sciences, Paleontology \& Geobiology, 80333 Munich, Germany

sResearch Center for Limnology, Indonesian Institute of Sciences (LIPI), Jl. Raya Bogor, Cibinong, Bogor, West Java 16911, Indonesia

9Insitute of Earth and Environmental Science, University of Potsdam, Potsdam, Germany

10Faculty of Mining and Petroleum Engineering, Institut Teknologi Bandung, Jl. Ganesha 10, 40132 Bandung,

Jawa Barat, Indonesia

IIInstitute of Geological Sciences \& Oeschger Centre for Climate Change Research, University of Bern,

Baltzerstrasse 1-3, 3012 Bern, Switzerland

12Institute of Geology and Mineralogy, University of Cologne, Zülpicher Str. 49a, D-50674 Cologne, Germany

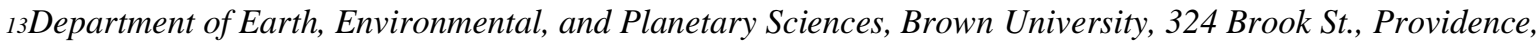
RI, 02912, USA

$\%$ both authors contributed equally to the manuscript

*Corresponding authors: Dr. Jens Kallmeyer and Dr. Sean Crowe

Addresses:

GFZ German Research Centre for Geosciences, Section 3.7. Geomicrobiology, Telegrafenberg, 14473 Potsdam, Germany, Phone: +49 (0) 331 28828785, email address: jens.kallmeyer@gfz-potsdam.de

Department of Microbiology and Immunology and Department of Earth, Ocean, and Atmospheric Sciences, University of British Columbia, 2350 Health Sciences Mall, Life Sciences Centre, Vancouver BC, CanadaV6T 1Z3, Phone: +1604-827-3827, email address: sean.crowe@ubc.ca 


\begin{abstract}
Ferruginous sediments were widespread during the Archaean and Proterozoic Eons, but our knowledge about organic matter mineralization remains mostly conceptual, as analogous modern ferruginous sediments are largely unstudied. In sediments of ferruginous Lake Towuti, Indonesia, methanogenesis dominates organic matter mineralization despite abundant reactive ferric iron phases persisting throughout the core. This implies that ferric iron can be buried over geologic timescales even in the presence of labile organic carbon. Iron reactivity and hence its contribution to organic matter mineralization is highly variable. With negligible methane oxidation, methane may diffuse from the sediment into the water column and reach the atmosphere. We hypothesize that similar conditions prevailed during the Archaean and Proterozoic Eons, and thus, may have contributed to regulating Earth's early climate.
\end{abstract}

Keywords: ferruginous sediments, Lake Towuti, methanogenesis, iron reduction

\title{
Introduction
}

Atmospheric chemistry, and its evolution over geological time, is intrinsically linked to the burial and mineralization of organic matter 1. Burial of organic matter can be a net source of oxidants (like oxygen) as well as a net sink of $\mathrm{CO}_{2}$, and its mineralization can result in production of greenhouse gasses like methane 2. In modern marine sediments, overlain by oxygenated bottom waters with abundant sulfate, much of the organic matter mineralization proceeds via a combination of aerobic respiration and sulfate reduction 3 and methanogenesis is considered the terminal step of carbon mineralization 4. In these sediments, more than $90 \%$ of the produced methane is consumed within the sediment through anaerobic oxidation of methane with sulfate as terminal electron acceptor 5. Oxygen exposure also directly controls sedimentary organic carbon preservation and bottom water anoxia increases carbon burial rates 6. The Precambrian ocean-atmosphere system was much different than today's - the atmosphere was only weakly oxygenated, seawater was sulfate poor, and the oceans were generally characterized by ferruginous (anoxic, Fe-rich) conditions 7, 8. Precipitation of Fe from these oceans resulted in the widespread deposition of ferruginous shales and, in more extreme cases, banded iron formations (BIFs) 8. The fate of organic matter, and biogeochemical cycling of climatically important trace gases, in Precambrian sediments is thus intrinsically linked to coupled $\mathrm{C}$ and Fe cycling.

In the complete, or near, absence of oxygen, nitrate and sulfate, organic matter mineralization in ferruginous sediments would be expected to proceed anaerobically via the 
energetically most favorable terminal electron acceptors available - in this case ferric iron, followed by $\mathrm{CO}_{2}$ through methanogenesis 4 . Prior work in freshwater and wetland sediments indeed shows that iron reducing bacteria outcompete methanogens for electron donors 9 , even when Fe(III) is supplied in the form of more crystalline (oxyhydr)oxides like goethite $(\mathrm{FeOOH})$, provided surface area is sufficiently high to allow microbial access to Fe(III) surface sites 10. Laboratory studies with synthetic and natural silica-rich Fe (oxyhydr)oxides and enrichment cultures further imply that Fe(III) can be effectively reduced when sufficient carbon is supplied 11,12. The role of Fe-reduction in organic matter mineralization, however, remains largely untested in $\mathrm{Fe}$ (III)-rich modern ferruginous environments analogous to those of the Precambrian oceans. Studies in the permanently stratified water column of Lake Matano, Indonesia 13 suggest that, despite abundant iron, methanogenesis is responsible for up to $90 \%$ of the total anaerobic organic matter mineralization. Process rates, however, were not measured in the Lake Matano study, whereas the enrichment culture experiments 11,12 were conducted in the laboratory under conditions that deviate considerably from likely environmental conditions. The role of methanogenesis, in both modern and ancient ferruginous sediments therefore remains largely untested through direct measurements in the natural environment.

We recovered modern ferruginous sediments from Lake Towuti, Indonesia, and used a suite of biogeochemical analyses to directly determine rates and pathways of organic matter mineralization. Lake Towuti is situated on Sulawesi Island, has a maximum water depth of $203 \mathrm{~m}$ (Fig. 1) and is weakly thermally stratified with a well-mixed, oxygenated surface layer that extends to $70 \mathrm{~m}$ depth, and waters below $130 \mathrm{~m}$ that are persistently anoxic 14 . Intensive weathering of ophiolitic bedrock from the catchment supplies the lake with a strong influx of iron (oxyhydr)oxides and runoff that contains little sulfate, leading to sulfate poor $(<20 \mu \mathrm{M})$ lake water and anoxic ferruginous conditions with Fe(II) concentrations up to $40 \mu \mathrm{M}$ below 130m 14. Similar conditions were also reported in nearby Lake Matano, which is considered broadly analogous to Precambrian ferruginous oceans 15 . The Fe (oxyhydr)oxide flux to Lake Towuti is comprised mainly of poorly- to nanocrystalline goethite with lesser amounts of hematite and magnetite, all of which may have been reworked and recrystallized to some extent during transport or through redox cycling in the uppermost sediments before burial 16.

As part of the Towuti Drilling Project (TDP) of the International Scientific Drilling Program (ICDP), we recovered sediment from a water depth of $156 \mathrm{~m}$ (Fig. 1) 17, well below the oxycline at the time of sampling 18 . This drill core was supplemented with short $(<0.4 \mathrm{~m})$ gravity cores that better preserve the sediment-water interface (SWI). Radiocarbon dating 
revealed a nearly constant sedimentation rate of $19 \mathrm{~cm} \mathrm{ka-1,} \mathrm{yielding} \mathrm{an} \mathrm{estimated} \mathrm{age} \mathrm{of} \sim 60$ ka at $12 \mathrm{~m}$ depth 19.

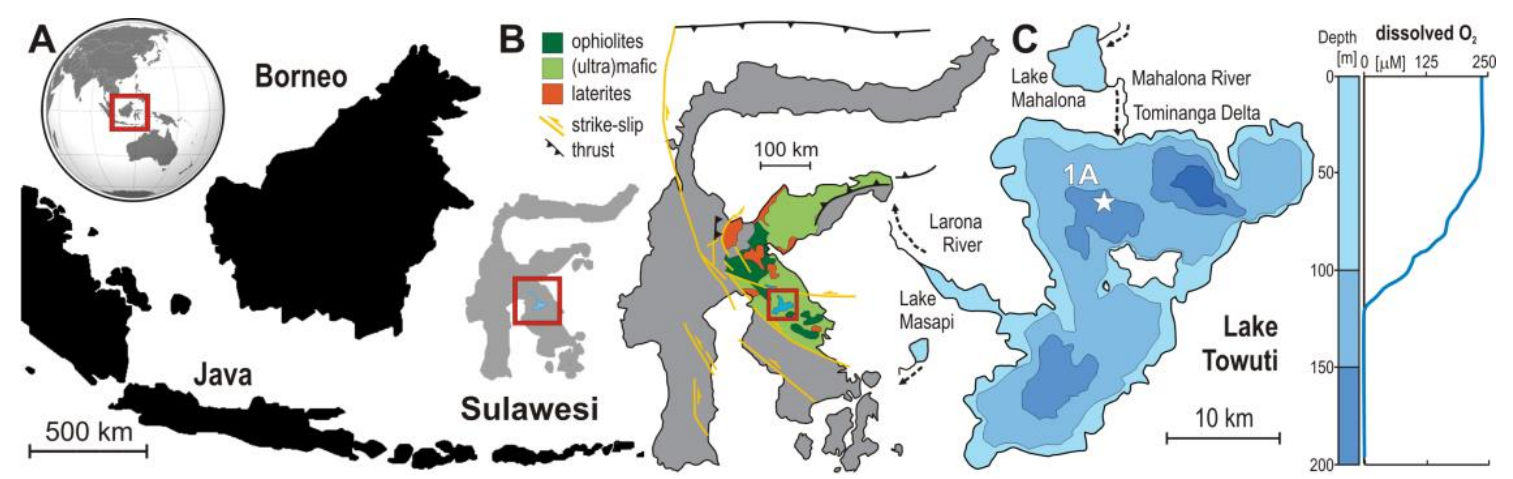

Figure 1: Lake Towuti location and geological setting: Map of Sulawesi Island illustrating the geological setting of the Malili Lake system, a chain of five tectonic lakes, with Lake Towuti being the largest. The white star on the bathymetric map marks the location of the drilling site $1 \mathrm{~A}$, which is located at a water depth of $153 \mathrm{~m}$, well below the depth of the oxycline $(130 \mathrm{~m})$. Figure modified after 14

\section{Results}

\section{Sediment and pore water geochemistry}

Lake Towuti's sediment is rich in organic carbon (TOC 0.4-4 wt\%) with elemental compositions implying that it is reactive (molar C:N ratio 11-25), readily fermentable (Fig. 2), and consequently reactive towards microbial respiration. Given a sedimentation rate of $19 \mathrm{~cm}$ ka-1 19 and a bulk density of $1.3 \mathrm{~g} \mathrm{~cm}-3$, these organic carbon concentrations translate to an organic carbon accumulation rate between 220 and $1800 \mathrm{mmol} \mathrm{m-2} \mathrm{yr}-1$, which thus places an upper bound on rates of total sedimentary carbon respiration. Fermentation is a key step in organic matter mineralization and its main products are volatile fatty acids (VFA) and molecular hydrogen, which are known electron donors for iron reduction 20. We detected formate, acetate, lactate, propionate and butyrate (Fig. 3), all showing the highest concentrations in the upper 2-6 m. Ammonium, which is also a product of organic matter mineralization 4, reaches peak concentrations around $6 \mathrm{~m}$ (Fig. 3). DIC concentrations range from 2 to $4 \mathrm{mM}$, indicating that the system is well buffered with respect to $\mathrm{pH}$, which thus has a limited range of 6.8 to 7.2 (Fig. 4). Concomitantly high DIC and pore water Fe(II) concentrations lead to siderite (FeCO3) formation throughout the core (Tab. S3) 21. Taken together, these results indicate that microbial degradation of organic matter takes place throughout the sediment, with the highest rates observed in the upper $6 \mathrm{~m}$ below the SWI. 


\section{Sedimentary iron phases}

Lake Towuti's sediment has extremely high total Fe concentrations (Fig. 2), with maximum values $>2500 \mu \mathrm{mol} \mathrm{Fe} \mathrm{cm}-3$ (20 \% dry wt.). In most sediments, however, only a fraction of the total Fe pool is geochemically and biologically reactive and has the capacity to participate in redox-reactions associated with organic matter mineralization and sediment diagenesis 22. We thus conducted a suite of selective sequential extractions to determine both the reactive fraction of the sedimentary Fe pool and its transformations during organic matter mineralization and diagenesis in Lake Towuti's sediments (Fig. 2).

Extraction with $0.5 \mathrm{~N} \mathrm{HCl}(\mathrm{Fe} \mathrm{HCl})$ captures the non- to poorly-crystalline ferric iron (Fe(III)) oxyhydroxides (e.g. ferrihydrite, lepidocrocite), generally considered to be the most available to Fe-respiring microorganisms 23, as well as corresponding respiration products including sorbed $\mathrm{Fe}(\mathrm{II})$, poorly crystalline siderite, and green rust 24, 25. In the FeHCl fraction, $\mathrm{Fe}(\mathrm{II})$ is abundant at all depths, comprising up to $30 \%$ of the total $\mathrm{Fe}$ pool, but $\mathrm{Fe}(\mathrm{III})$ in these pools is below our limit of detection $(10 \mu \mathrm{mol} \mathrm{cm-3)}$ in all samples. So, despite very high total Fe concentrations, Fe(III) phases considered readily available to Fe-respiring microorganisms 23 are virtually absent from Lake Towuti's sediments. We also targeted more crystalline carbonate phases like siderite with a sodium acetate (Feaca) extraction, which liberated an appreciable amount of $\mathrm{Fe}(\mathrm{II})$ but no detectable Fe(III).

$\mathrm{Fe}(\mathrm{III})$ phases not extracted in $0.5 \mathrm{~N} \mathrm{HCl}$, like goethite, hematite, and $\mathrm{Fe}(\mathrm{III})$-bearing clays like nontronite, can also be respired under some laboratory and environmental conditions 26 and such phases have been shown to react with hydrogen sulfide in marine sediments 27. These phases are thus also considered part of the reactive Fe(III) pool and expected to play a role in sediment diagenesis. We therefore targeted these phases using sodium dithionite extractions (Fedith) 24 and found them to be abundant in Lake Towuti's sediments, comprising up to $880 \mu \mathrm{mol} \mathrm{cm}-3$ of the total Fe pool (Fig. 2). Reactive Fe present in magnetite was targeted using an ammonium oxalate/oxalic acid leach (Feoxa). Together, Fedith and Feoxa represent a theoretically bioavailable Fe(III) pool which accounts on average $320 \mu \mathrm{mol} \mathrm{cm}-3$ or $31 \%$ of the total Fe, but this pool shows little variation with depth. The only exception is a notable decrease in dithionite extractable Fe concentrations in the upper one $\mathrm{cm}$ below the SWI (Fig. 2).

\section{Modeling of iron reduction}

The apparent lack of Fe(III) reduction in much of the sediment is consistent with the pore water profiles of $\mathrm{Fe}_{2+}$ concentration and $\mathrm{pH}$, which would be expected to decrease in response 


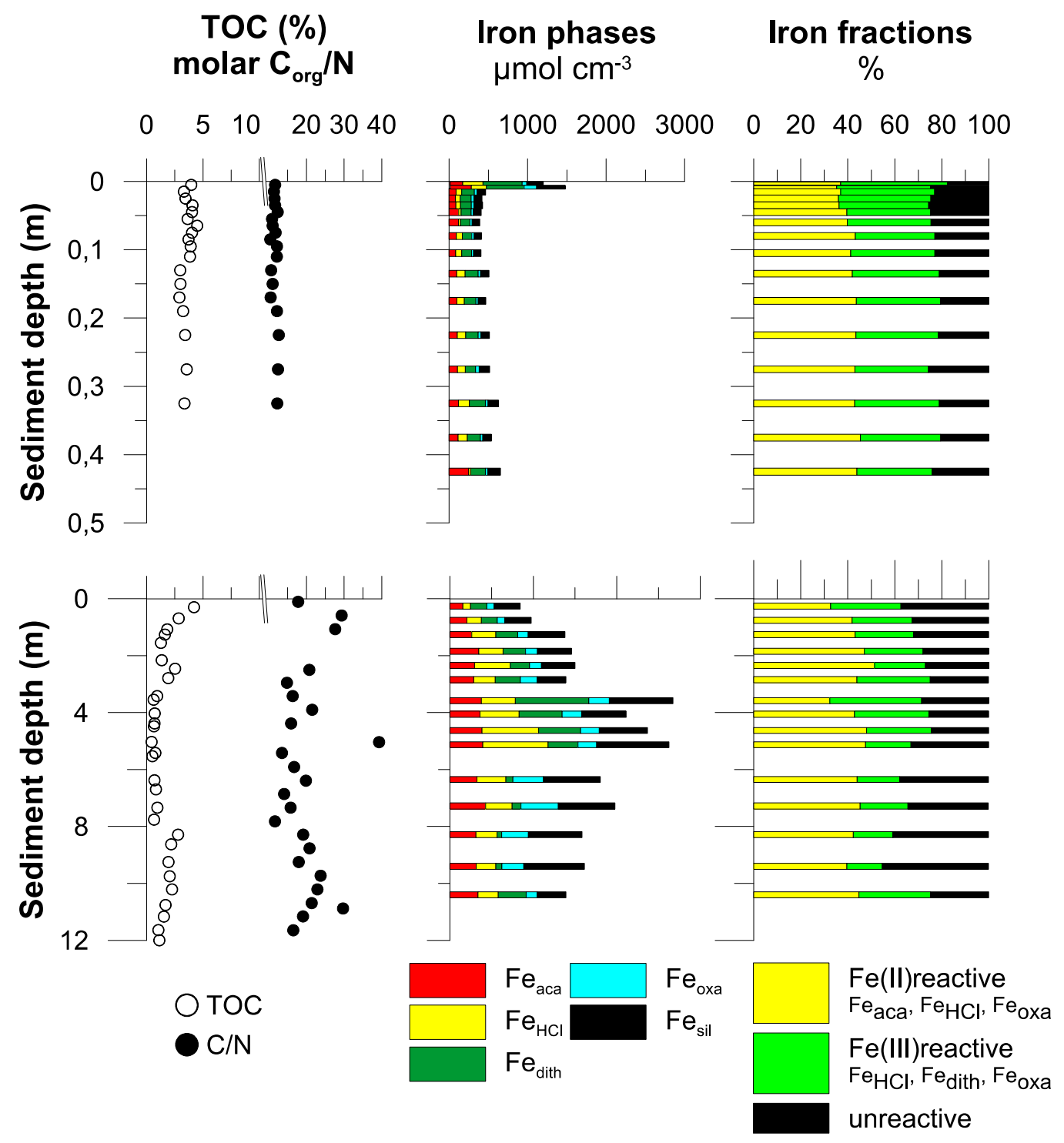

Figure 2: Sediment characteristics Total organic carbon content in bulk sediment and molar $\mathrm{Corg}_{\mathrm{or}} \mathrm{N}$ ratio (left row), sequentially extracted iron phases (center row) and iron fractions (right row) of Lake Towuti sediment of the short $(<0.4 \mathrm{~m})$ gravity core (upper panel) and the $12 \mathrm{~m}$ TDP drill core (lower panel). See main text and supplementary material for detailed description of the iron phases. Total organic carbon content as well as molar $\mathrm{Corg}_{\mathrm{N}} \mathrm{N}$ ratios of the short gravity core were taken from Vuillemin et al. (2016)14. Note, that Fe(III) within the Fенсl fraction was below our limit of detection so that the reactive Fe(III) pool is composed entirely of the Fedith and Feoxa fraction.

to appreciable Fe(III) reduction (Fig. 4). Modeling based on diffusive fluxes of pore water $\mathrm{Fe}_{2}+$ indicates very low net rates of background $\mathrm{Fe}$ (III) reductive dissolution $(\sim 1 \mathrm{mmol} \mathrm{m}-2 \mathrm{y}$ 1) in the upper $4 \mathrm{~m}$ (Fig. 3). Modeling based on solid phases indicates that Fe(III) reduction rates are highest in the upper $1 \mathrm{~cm}$, just below the SWI (53 mmol m-2 yr-1), and the depthintegrated $\mathrm{Fe}(\mathrm{III})$ reduction rate for the remaining $12 \mathrm{~m}$ is $105 \mathrm{mmol} \mathrm{m}-2 \mathrm{yr}-1$, resulting in a 
total depth-integrated Fe reduction rate of $160 \mathrm{mmol} \mathrm{m-2} \mathrm{yr}-1$ over the upper $12 \mathrm{~m}$. Assuming a 4:1 stoichiometry of iron reduction coupled to organic carbon oxidation 28 , this translates to an organic carbon degradation rate of $40 \mathrm{mmol} \mathrm{m-2} \mathrm{yr}_{-1}$, which is low compared to total organic carbon accumulation rates at the SWI. These observations thus reveal that microbial Fe reduction is restricted to the uppermost sediment layer in Lake Towuti and imply that the $\mathrm{Fe}(\mathrm{III})$ phases present are stable throughout the sediment studied for over tens of thousands of years.

\section{Quantification of sulfate reduction rates}

Given the apparently minor role of Fe reduction alongside the relatively high abundances of canonically reactive $\mathrm{Fe}(\mathrm{III})$ and labile organic matter, we explored other pathways of organic matter mineralization. Sulfate reduction commonly follows iron reduction in order of decreasing free energy yield in marine sediments 4. Pore water sulfate concentrations in Lake Towuti are extremely low and decrease from $15 \mu \mathrm{M}$ at the SWI to below our detection limit $(1 \mu \mathrm{M})$ in the upper $\mathrm{cm}$ of the sediment (Fig. 3). Nevertheless, while geochemical modeling predicts sulfate reduction in the upper $4 \mathrm{~m}$ (Fig. S2), radiotracer incubation experiments reveal potential for sulfate reduction over the entire $12 \mathrm{~m}$ depth interval (Fig. 3). Depthintegrated rates of measured potential sulfate reduction (pSRR) are $20 \pm 10 \mathrm{mmol} \mathrm{m}-2 \mathrm{yr}-1$, while modeled depth-integrated rates of sulfate reduction are $0.2 \pm 0.15 \mathrm{mmol} \mathrm{m}-2 \mathrm{yr}-1$, which correspond to an organic carbon oxidation rate of $40 \pm 20 \mathrm{mmol} \mathrm{m}-2 \mathrm{yr}-1$ and $0.40 \pm 0.3 \mathrm{mmol}$ $\mathrm{m}-2 \mathrm{yr}-1$, respectively, based on a 1:2 stoichiometry between sulfate reduction and organic carbon oxidation. Due to appreciable deviations from in-situ conditions (see supplementary material for details) the measured pSRR should be treated with caution and taken instead as an indication of metabolic potential only. We thus assumed that the measured pSRR and the modeled rates represent the respective upper and lower estimates of true sulfate reduction rates, respectively. We conclude that, like iron reduction, sulfate reduction plays only a minor role in organic matter degradation. Nevertheless, and importantly, the observation that sulfate reduction persists throughout the core confirms microbial reactivity of organic matter in these sediments. 

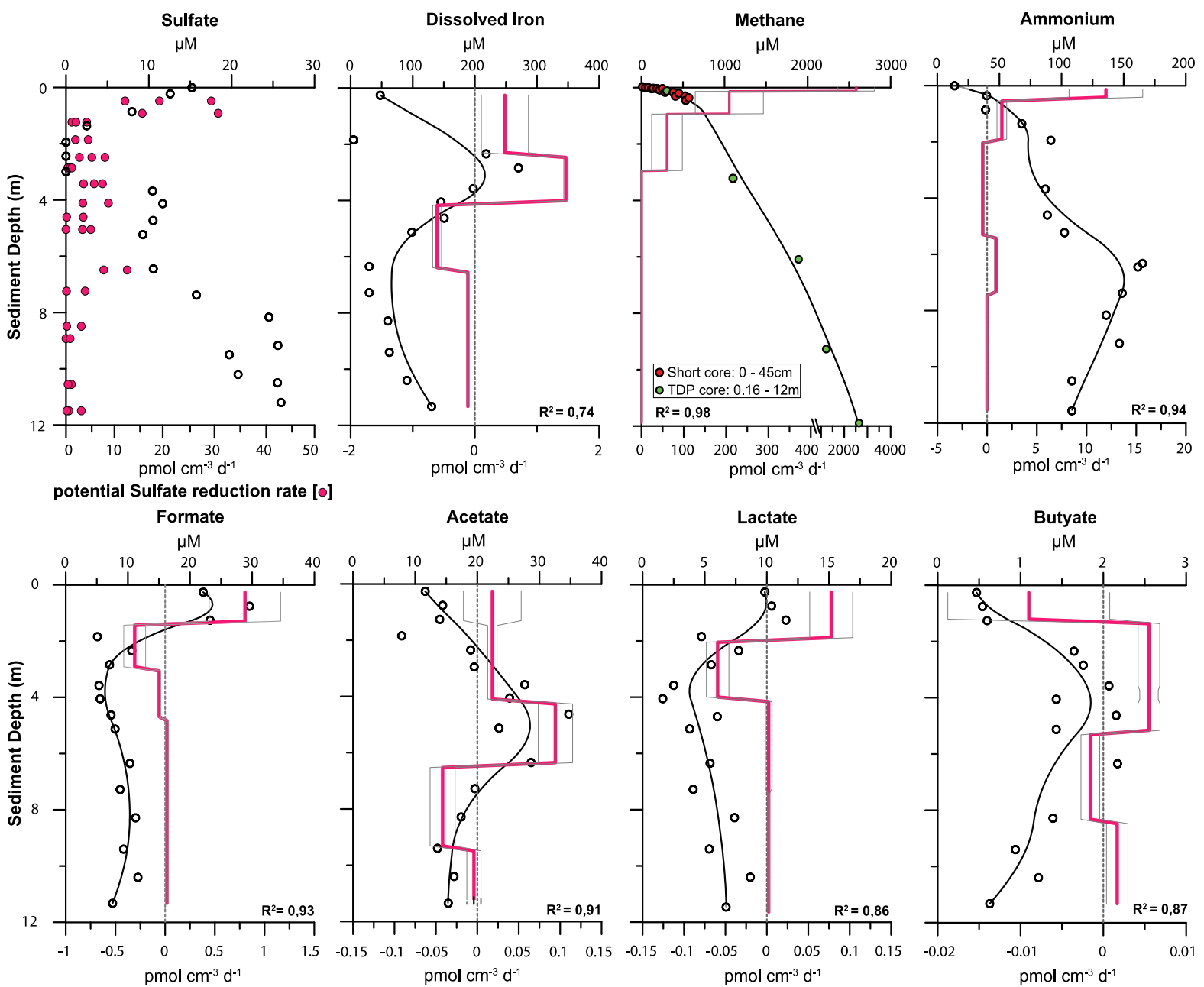

Figure 3: Pore water chemistry of reactants involved in organic matter mineralization:

Open circles show concentrations in sediment pore water, pink circles indicate potential sulfate reduction rates (pSRR), determined by radiotracer experiments. The black lines show the modeled concentration profiles (see supplementary material, SM), $\mathrm{R}_{2}$ showing the correlation coefficient of the fit. The pink solid line shows the calculated mean reaction rate profile together with its standard deviation (grey line). Top xaxis shows the concentration, bottom $\mathrm{x}$-axis indicates the reaction rate, positive values indicate net production, negative values net consumption of the respective compound. See also table S4.

\section{Quantification of methanogenesis rates}

Methanogenesis is commonly considered to be the final step in organic matter mineralization as it has the lowest free energy yield in the canonical cascade of early diagenetic redox reactions. In Lake Towuti, pore water methane concentrations increase continuously from $23 \mu \mathrm{M}$ at the SWI to $2600 \mu \mathrm{M}$ at $12 \mathrm{~m}$ depth (Fig. 3). The accumulation of methane throughout the sediment and the concave-upwards shaped concentration profile imply that methanogenesis occurs at all depths. This is further supported by our modeling based on pore water methane concentrations (Figs. 3 and S3) as well as by incubation-based 
measurements of potential hydrogenotrophic and acetoclastic methane production (Fig. S1). Sediment samples from three depths $(0.36 \mathrm{~m}, 2 \mathrm{~m}$ and $7.4 \mathrm{~m})$, reveal the potential for methanogenesis at these depths and by both pathways. The fact that methane concentrations at the SWI are not zero indicates a diffusive methane efflux out of the sediment into the water column (Figs. 3 and S3). Our modeling results are also supported by the stable isotopic composition of pore water $\mathrm{CH}_{4}$ and $\mathrm{CO}_{2}$. The $\delta_{13} \mathrm{C}$ - and $\delta \mathrm{D}$-values of methane are around -70\% vs VPDB and -170\%o vs VSMOW, respectively (Fig. 4). Despite some variation with depth these values are well in the range considered to be indicative for biogenic methane. The almost parallel increase of $\delta{ }_{13} \mathrm{C}\left(\mathrm{CH}_{4}\right)$ and $\delta{ }_{13} \mathrm{C}\left(\mathrm{CO}_{2}\right)$ is consistent with the consumption of $\mathrm{CO}_{2}$ by hydrogenotrophic methanogenesis 29 . The modeled depth-integrated rate of methane production over the upper $12 \mathrm{~m}$ was $220 \pm 90 \mathrm{mmol} \mathrm{m-2} \mathrm{yr-1} \mathrm{(fig.3,} \mathrm{table} \mathrm{S4).}$ Assuming a 2:1 stoichiometry for the conversion of organic matter to methane, methanogenesis accounts for the conversion of $440 \pm 170 \mathrm{mmol} \mathrm{m}-2 \mathrm{yr}-1$ organic carbon. This rate far exceeds those of all other carbon mineralization processes combined but is still less than, and therefore approximately balanced by, the carbon accumulation rate. Within the upper $12 \mathrm{~m}$ of sediment, sulfate reduction, iron reduction, as well as methanogenesis combined add up to a total organic carbon mineralization rate of $519 \pm 191 \mathrm{mmol} \mathrm{m}-2 \mathrm{yr}-1$, with methanogenesis being the dominant process ( $85-92 \%)$ followed by iron reduction $(8 \%)$ and sulfate reduction $(<1-7 \%)$.

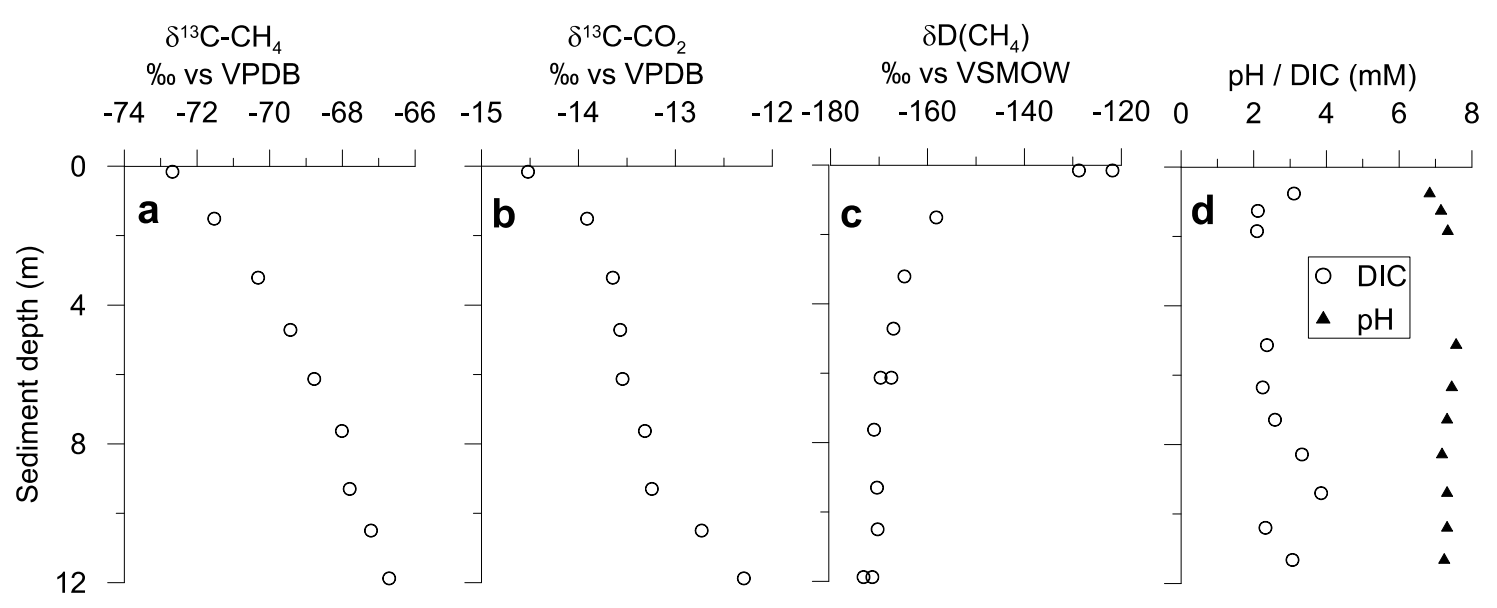

Figure 4: a) stable carbon isotopic composition of methane, b) stable carbon isotopic composition of carbon dioxide, c) deuterium composition of methane, d) pore water $\mathrm{pH}$ and DIC concentration. See main text and supplement for details 


\section{Discussion}

Our data demonstrate that methanogenesis is the dominant (> $85 \%$ ) pathway for carbon mineralization in Lake Towuti sediment and that Fe(III) reduction plays a relatively minor role in these sediments despite an abundance of biologically reducible Fe(III) bearing minerals. While there is the potential for sulfate reduction throughout the upper $12 \mathrm{~m}$, as shown by our pSRR data, this process does not make a quantitatively important contribution to total organic carbon mineralization. Fe-reduction also plays a relatively minor role in these sediments, which is remarkable considering the high abundance of Fe(III)-containing minerals. The apparent stability of Fe-oxides in Lake Towuti contrasts with the expected reactivity towards biological Fe(III) reduction based on both laboratory and environmental experiments with nanocrystalline to crystalline goethite and hematite 10,26 . The reason for the apparent lack of reactivity may be linked to the ultimate source of Lake Towuti's detrital iron (oxyhydr)oxides from the surrounding soils, which can be highly crystalline with low surface area 30. Prior studies at Lake Towuti, however, suggest that regardless of source, sedimentary iron (oxyhydr)oxides are poorly crystalline and may have experienced strong reworking prior to burial 16 - such conversion to authigenic phases would likely render them more reactive towards reduction. Perhaps a more likely explanation for low reactivity is surface passivation through $\mathrm{Fe}$ (II) sorption 31, 32, which would be important at the 10s-100s of $\mu \mathrm{M}$ Fe(II) present in Lake Towuti's pore waters (Fig. 3).

Microbial methanogenesis produces most of the methane on Earth, but in modern marine sediments with abundant sulfate anaerobic oxidation of methane (AOM) consumes more than $90 \%$ of the total methane produced, thereby providing a buffer between sedimentary methane production and the atmosphere 5. In environments where sulfate is scarce, AOM has been linked to the reduction of nitrate 33, 34 and $\mathrm{Fe}$ (III) 35. With nitrate and nitrite below the limit of detection $(4 \mu \mathrm{M})$ and very little sulfate, Fe-dependent AOM remains the only pathway with potential to quantitatively consume methane in Lake Towuti's sediment. While it is true that tightly coupled methane production and oxidation could be masked in pore water profiles 36 , the process would cause a decline in oxidant concentration, in this case Fe(III), which we do not observe. Pore water profiles also show no evidence for net methane consumption and Fe-reduction rates are small, so we thus conclude that AOM is generally negligible in Lake Towuti's sediments, as the known electron acceptors are either not available $\left(\mathrm{NO}_{3}, \mathrm{NO}_{2}, \mathrm{SO}_{4}\right)$ or not utilized (Fe(III)).

Previous studies have shown the metabolic potential for coupled $\mathrm{Fe}, \mathrm{S}$ and $\mathrm{C}$ cycling 37, which could possibly operate cryptically 38 . Such cryptic cycles are important in many 
environments and we cannot rule them out in Lake Towuti's sediments. However, even cryptic cycles are constrained by mass balance. In the case of Lake Towuti, a cryptic sulfur cycle would need to be supported by an oxidant and the only oxidant of sufficient abundance to sustain appreciable cryptic sulfur cycling throughout the core is Fe(III). Since Fe(III) is largely stable downcore, mass balance dictates that cryptic sulfur cycling would have to operate at rates much lower than Fe(III) deposition and burial and thus, we argue that such cryptic sulfur cycling is insignificant to overall net sediment $\mathrm{Fe}$ and $\mathrm{CH}_{4}$ budgets.

Though the specific reasons for the apparent lack of Fe(III) reactivity in Lake Towuti remain somewhat uncertain, the dominance of methanogenesis has strong implications for coupled carbon and iron cycling in the Precambrian oceans. Robust extension of our results to these Eons, however, depends on comparisons between the authigenic and detrital Fe mineral phases in Lake Towuti and those of mainly hydrothermal provenance expected to form in the Precambrian oceans. Notably, crystallinity, through its control on surface area of the relevant phases, would be expected to play an important role in reactivity 39 . While poorly crystalline goethite dominates Lake Towuti's Fe pool, Fe (oxyhydr)oxides in the Precambrian oceans may have had even greater surface areas and therefore reactivity 26,39. There is considerable debate on the nature of the primary Fe phases deposited from the Precambrian oceans. High, but uncertain concentrations of seawater silica would likely have hindered the transformation of poorly crystalline hydrous ferric oxides into more crystalline, and therefore less reactive phases like the poorly crystalline goethite found in Lake Towuti 40. We note, however, that the silica concentrations in Lake Towuti and catchment waters $(\sim 300 \mu \mathrm{M})$ indeed approach the lower end of experimentally estimated silica concentrations $(600-1500 \mu \mathrm{M})$ in the Precambrian oceans 41 and we thus speculate similar, but possibly muted, effects on Fe speciation in Lake Towuti. Nevertheless, given that the Fe (oxyhydr)oxides in Lake Towuti may be less biologically reducible than those perceived for the Precambrian oceans, we take our results from Lake Towuti as an end member scenario for reconstructing the role of Fe reduction in Precambrian marine organic matter mineralization. In contrast, we consider prior work from Chocolate Pots hot springs, where silica concentrations reach $2.5 \mathrm{mM}$ 11, as the possible other end member. Such high silica concentrations, which are higher than what has been estimated for the Precambrian oceans, lead to preservation of poorly crystalline, silicarich hydrous ferric oxides 11 , of which $\sim 80 \%$ of their Fe(III) is reduced by organic matter oxidation 11,12 .

Photosynthesis in the Archean and Proterozoic Eons would have led to the production of organic matter, and under ferruginous ocean conditions, the deposition of $\mathrm{Fe}(\mathrm{III})$-rich 
sediments, either through direct photosynthetic Fe-oxidation (photoferrotrophy) 15 or through reaction of $\mathrm{Fe}(\mathrm{II})$ with oxygen produced through oxygenic photosynthesis 42 . Rates of organic matter production through photosynthesis during much of the Precambrian Eons were likely between 1 and $10 \%$ of modern values, or 40-400 Tmol yr-1 43,44 and if organic carbon burial efficiency was comparable to the modern (1-10\%) 45, 46, this translates to global mineralization rates between 36 and 396 Tmol yr-1. While both Fe-reduction and methanogenesis likely evolved early in the Archean Eon 47, 48, analogy to Lake Towuti would suggest that much of the Fe(III) produced through photosynthesis could have been buried without appreciable respiration and reduction coupled to oxidation of co-deposited organic carbon. In contrast, if silica-rich hydrous ferric oxides, like those from Chocolate Pots are closer in reactivity to the Fe(III) produced through photosynthesis in the Archean Eon, then a greater fraction of the photosynthetic biomass would have been respired through $\mathrm{Fe}$ (III) reduction. These analogies can be tethered to the geological record by considering the redox state of Fe preserved in BIFs, which on average is 2.6 49, implying that at least $60 \%$ of the $\mathrm{Fe}(\mathrm{III})$ is commonly preserved and buried. While this preservation can, in part, be explained through physical separation of Fe(III) from organic matter 49, it also likely reflects the reactivity of $\mathrm{Fe}(\mathrm{III})$ phases. Variability (2.08 to 2.97 ) in this redox state across facies, between deposits, and through time could thus be partly explained, and even provide evidence for $\mathrm{Fe}(\mathrm{III})$ reactivity as a controlling factor in the extent of microbial Fe(III) reduction. The extent of decoupling from Fe-reduction would have controlled organic matter accumulation in sediments and rates of methanogenesis.

To assess potential scenarios for carbon mineralization via methanogenesis under different Fe(III) reactivities we used Lake Towuti's sediment as the low Fe(III) reactivity end member, and silica-rich, hydrous ferric oxides sediments like Chocolate Pots, where $80 \%$ of the $\mathrm{Fe}(\mathrm{III})$ is reduced 11, 12, as the high $\mathrm{Fe}(\mathrm{III})$ reactivity end member. For the low reactivity end member, breakdown of 85-92\% of organic carbon through methanogenesis would have led to marine $\mathrm{CH}_{4}$ production of 15-180 Tmol yr-1. For the high reactivity end member, we assumed a total Fe concentration of $40 \mathrm{wt} \%$, which is the highest Fe concentration reported for BIFs 50 and twice as much as in Lake Towuti. The exact composition of primary Fe minerals in BIFs is still under debate but we assumed that the iron-silica coprecipitates which are assumed to be the primary form of sedimentary Fe in the Archaean and Proterozoic Ocean51, 52 have a density similar to that of Opal $(2.3 \mathrm{~g} \mathrm{~cm}-3)$ and that porosity in the upper and most reactive few meters of seafloor is on average $70 \%$. This results in a total $\mathrm{Fe}$ concentration of $5 \mathrm{mmol} \mathrm{cm}$-3. Other easily reducible non- to poorly-crystalline ferric iron 
oxyhydroxides phases (e.g. ferrihydrite or lepidocrocite) with a higher bulk density might also contribute to the sedimentary Fe(III) pool. Even when assuming a particle density of 3, this would only increase the total Fe concentration in the sediment by about $21 \%$ to $6.3 \mathrm{mmol} \mathrm{cm}$ 3.

We also assumed the sediment to be entirely composed of Fe(III), which is most probably a gross overestimate, given the results from BIFs 49 and further we assume that $\sim 80 \%$ of the Fe(III) is reducible like in Chocolate Pots11,12. With Lake Towuti's sedimentation rate of 19 $\mathrm{cm} \mathrm{ky}-1$, and a 4:1 stoichiometry of iron reduction coupled to organic carbon oxidation 28 , this results in a carbon mineralization rate of ca. $200 \mathrm{mmol} \mathrm{m-2} \mathrm{yr}-1$ through iron reduction. Using the same total organic carbon mineralization rate $(519 \pm 191 \mathrm{mmol} \mathrm{m}-2 \mathrm{yr}-1)$ as for Lake Towuti, iron reduction alone would account for 28 to $61 \%$ of total carbon mineralization in the high Fe(III) reactivity scenario. Although cryptic sulfur cycling might be quantitatively more important under high $\mathrm{Fe}(\mathrm{III})$ reactivity conditions, it would significantly decrease the $\mathrm{Fe}(\mathrm{III})$ pool and thereby reduce iron reduction because it requires reduction of 8 moles of $\mathrm{Fe}(\mathrm{III})$ to reoxidize 1 mole of hydrogen sulfide back to sulfate. We therefore use the same rate of carbon mineralization rate via sulfate reduction (0.1-60 mmol m-2 yr-1 or 0.01 to $19 \%)$ as for the low Fe(III) reactivity scenario. All carbon that is not mineralized via sulfate or iron reduction is mineralized via methanogenesis, which results in a carbon mineralization rate of 70-510 mmol m-2 yr-1 or 21-72\%. This would have led to marine $\mathrm{CH}_{4}$ production of 4-143 Tmol $\mathrm{yr}-1$. One of the main reasons for the limited contribution of iron reduction to carbon mineralization even under most favorable conditions is the $4: 1$ stoichiometry of the reaction. With respective ratios of $1: 2$ and 2:1 for sulfate reduction and methanogenesis, these processes are up to eight times more efficient in mineralizing organic carbon. Thus, under ferruginous conditions methanogenesis will remain a major mineralization pathway even with ample available reactive $\mathrm{Fe}(\mathrm{III})$.

In oceans lacking appreciable oxygen and sulfate 7, this sedimentary methanogenesis fueled by organic matter would, in the absence of AOM, have led to equivalent effluxes of $\mathrm{CH}_{4}$ to the overlying anoxic oceans and atmosphere. Atmospheric $\mathrm{CH}_{4}$ concentrations can be approximated through new solutions to photochemical models for a given biospheric $\mathrm{CH}_{4}$ production flux 53, which imply a wide range of concentrations from 40 up to $24000 \mathrm{ppmv}$, depending on biological productivity, organic carbon burial efficiencies, and importantly, the reactivity of sedimentary Fe minerals towards biological reduction. Such strong upper predicted Precambrian biospheric $\mathrm{CH}_{4}$ fluxes and atmospheric $\mathrm{CH}_{4}$ concentrations, versus previous work 53, are largely the result of the high conversion efficiency of organic carbon to 
$\mathrm{CH}_{4}$, as observed in lake Towuti's sediments. We note that atmospheric methane concentrations in the Precambrian may thus be a function of Fe(III) mineral crystallinity and reactivity and could vary strongly in response to changes in the factors that control this reactivity, including seawater silica concentrations. Resolving the wide range in possible Precambrian atmospheric methane concentrations thus requires both tighter constraints on Precambrian primary production, as well as the nature of the primary $\mathrm{Fe}(\mathrm{III})$ mineral precipitates and their dynamics through time. However, irrespective of the reactivity of $\mathrm{Fe}(\mathrm{III})$ minerals, methanogenesis will be a quantitatively important pathway for carbon mineralization in ferruginous sediments.

\section{Materials and Methods}

ICDP drilling campaign and sampling procedure

In 2015 a scientific drilling campaign took place on Lake Towuti within the framework of the International Continental Scientific Drilling Program (ICDP). We retrieved a $~ 115 \mathrm{~m}$ long sediment core dedicated for geomicrobiological investigations from Drill Site 1 at a water depth of 153 m using the ICDP Deep Lakes Drilling System 17. We used a tracer to monitor infiltration of drilling fluid into the core 54 and only used uncontaminated samples for our analyses. Our study focused on the upper 12 meters of the drill core, a section equivalent to sediments that have already been subject to comprehensive paleoclimatic investigations, which also supplied sediment ages and estimates of sedimentation rates 18. Cores were collected in HQ-size butyrate liners ( $66 \mathrm{~mm}$ core diameter) in $3 \mathrm{~m}$ intervals using hydraulic piston coring. After retrieval, sediment cores were cut into two subsections of $1.5 \mathrm{~m}$ length. In addition, short $(<0.4 \mathrm{~m})$ sediment cores were retrieved from the same site using a small gravity-coring device that recovered an undisturbed sediment-water interface (SWI) and allowed interrogation of the uppermost sediments in more detail.

\section{Pore water sampling and analysis}

Pore water was squeezed under anaerobic conditions. Concentrations of major cations and anions were analyzed by ion chromatography. Dissolved iron and phosphate concentrations were determined spectrophotometrically 55, 56. Concentrations of volatile fatty acids (VFAs) in the pore water were measured by 2-dimensional ion chromatography mass spectrometry (2D IC-MS) 57. 


\section{Iron speciation}

For iron speciation, a sub sample of $500 \mathrm{mg}$ of wet sediment from each core interval of both sediment cores was extracted in the field and immediately leached in $1 \mathrm{~mL} 0.5 \mathrm{~N} \mathrm{HCl}$, and Fe-speciation (Fe(II) and $\mathrm{Fe}(\mathrm{III})$ ) of the easily extractable Fe-phases was measured spectrophotometrically on site using a ferrozine assay 55, 58. The complete Fe-speciation protocol was performed on anoxically preserved and freeze-dried sediments milled to fine powders using an agate hand mortar and pestle. Sample masses of $200 \mathrm{mg}$ of sediment were weighed into $15 \mathrm{~mL}$ centrifuge tubes, and subjected to the Fe-speciation sequential extraction scheme based on the protocol of Poulton and Canfield 24:

- Fe in carbonate and poorly crystalline phases was extracted by leaching the sediment with a sodium acetate solution adjusted with acetic acid to $\mathrm{pH} 4.5$ with acetic acid for $48 \mathrm{~h}$ (Feaca). However, easily reducible ferric iron within the Feaca fraction was always below the limit of detection in all samples, so that this fraction entirely consists of ferrous iron.

- Leaching the sample with $0.5 \mathrm{M} \mathrm{HCl}$ for $1 \mathrm{~h}$ extracted the highly reactive $\mathrm{Fe}$ in hydrous ferric oxides like ferrihydrite or lepidocrocite ( $\mathrm{Fe} \mathrm{HCl})$.

- Reactive Fe in goethite and hematite was extracted by treating the sediment sample with a sodium dithionite solution (50 g L-1) buffered to $\mathrm{pH} 4.8$ with $0.35 \mathrm{M}$ acetic acid/0.2 M sodium citrate for $2 \mathrm{~h}$ (Fedith).

- Leaching the sediment sample with $0.2 \mathrm{M}$ ammonium oxalate/0.17 M oxalic acid solution ( $\mathrm{pH} 3.2$ ) for $6 \mathrm{~h}$ extracted the reactive Fe present in magnetite (Feoxa).

- Finally, samples were subjected to a near boiling $6 \mathrm{~N} \mathrm{HCl}$ extraction for $24 \mathrm{~h}$ to extract the remaining unreactive Fe in silicates (Fesil).

Our reactive Fe pool is defined as carbonate-associated $\mathrm{Fe}$ (Feaca, sodium acetate extractable $\mathrm{Fe}$ ), hydrous ferric oxides (Feнсl, $0.5 \mathrm{~N} \mathrm{HCl}$ extractable $\mathrm{Fe}$ ), ferric (oxy)hydroxides (Fedith, dithionite extractable $\mathrm{Fe}$ ), and magnetite (Feoxa, oxalate extractable $\mathrm{Fe}),($ Reactive $\mathrm{Fe}$ pool = $\mathrm{Fe}_{\mathrm{aca}}+\mathrm{Fe} \mathrm{HCl}+\mathrm{Fe}_{\text {dith }}+\mathrm{Fe}_{\mathrm{oxa}}$ ). The total reactive ferric Fe pool is defined as ferric iron present within the $\mathrm{FeHCl}, \mathrm{Fe}$ dith and within the Fe ${ }_{\text {oxa }}$ fraction. The total reactive ferrous iron pool is composed of the ferrous iron within the Feaca, Feнсl and Fe oxa fraction. Finally, the total iron pool is defined as the sum of all reactive Fe phases and non-reactive (lithogenic) Fe contained in silicate minerals (Fesil). 


\section{TOC analysis}

Total organic carbon was quantified by Rock-Eval 6 pyrolysis (Vinci Technologies).

\section{Methane concentrations and isotopic analysis}

To minimize losses due to outgassing sediment samples for methane concentration and isotopic analysis were taken with a cutoff syringe immediately after retrieval of the core and stored in glass vials filled with saturated $\mathrm{NaCl}$ solution without headspace. At least $24 \mathrm{hrs}$ prior to analysis we introduced $3 \mathrm{ml}$ of Helium as headspace. Methane concentrations were quantified by gas chromatography, isotopic composition measured with a continuous-flow isotope ratio mass spectrometer.

\section{Potential sulfate reduction rates}

Potential sulfate reduction rates were determined by incubation with radioactive ${ }_{35} \mathrm{SO}_{42-} 59$ using sterile glass plugs fitted with a syringe plunger to obtain undisturbed sediment mini-cores, the end was closed with butyl rubber stoppers.

Due to legal constraints it was not possible to carry out the radiotracer incubations on site. We therefore collected WRC, stored them in an $\mathrm{N}_{2}$ atmosphere and retrieved the subsamples for radiotracer incubations from the WRC several weeks after the drilling back in the home lab in Potsdam.

After pre-incubation for $24 \mathrm{~h}$ at the approximately in-situ temperature of $30^{\circ} \mathrm{C}$, ca. $100 \mathrm{kBq}$ of $35 \mathrm{SO}_{42}$ - tracer, containing $\sim 10 \mu \mathrm{M}$ of non-radioactive $\mathrm{SO}_{42}$ - in order to avoid complete turnover of the sulfate pool 60 was injected into each sample. Samples were incubated for $24 \mathrm{~h}$ at $30^{\circ} \mathrm{C}$ in the dark. Incubations were stopped by transferring the samples into $10 \mathrm{ml}$ of $20 \%$ Zinc Acetate solution. The microbially reduced inorganic sulfur species were separated from the remaining sample and the unreacted sulfate tracer using the cold chromium distillation 61 . Radioactivity was quantified by liquid scintillation counting. Because of the time lag between recovery of the core and the start of incubations the in-situ sulfate concentration and the autochthonous microbial community might have changed. We also added non-radioactive sulfate to the tracer. As we cannot quantify how these factors affect the sulfate reduction rates, we consider them to be potential, as the only conclusion that can be drawn unequivocally is that there is a microbial community that is able to perform sulfate reduction. 


\section{Geochemical modeling}

Net reaction rates of dissolved chemical species were calculated using the MATLAB script of Wang et al. (2008) 62, assuming that the pore water concentration profiles represent steady-state conditions.

\section{Potential methane production}

The potential for biogenic methane production was investigated by incubation experiments with sediment samples from three different depths $(0.36 \mathrm{~m}, 1.95 \mathrm{~m}$ and $7.4 \mathrm{~m})$. The sediment was slurried using sulfate-depleted freshwater medium mimicking the pore water concentrations of Lake Towuti sediment (Table S2). Incubations for hydrogenotrophic methanogenesis, the butyl stoppered glass crimp vial was flushed with a mixture of $\mathrm{H}_{2} / \mathrm{CO}_{2}$ $(80 / 20 \%)$.

\section{Data availability}

Pore water geochemistry and bulk sediment measurements of downcore profiles from site TDP-1A of the ICDP Towuti Drilling Project, Lake Towuti, Indonesia. https://doi.pangaea.de/10.1594/PANGAEA.908080

All other data discussed in the paper will be made available to readers in the supplement.

\section{Acknowledgements}

This research was carried out with partial support from the International Continental Scientific Drilling Program (ICDP), the U.S. National Science Foundation (NSF), the German Research Foundation (DFG), the Swiss National Science Foundation (SNSF), PT Vale Indonesia, the Ministry of Research, Education, and Higher Technology of Indonesia (RISTEK), Brown University, the University of Minnesota, the National Autonomous University of Mexico (UNAM), GFZ German Research Centre for Geosciences, the Natural Sciences and Engineering Research Council of Canada (NSERC), and Genome British Columbia. We thank PT Vale Indonesia, the US Continental Scientific Drilling and Coordination Office, and US National Lacustrine Core Repository, and DOSECC Exploration Services for logistical support. The research was carried out with permissions from RISTEK, the Ministry of Trade of the Republic of Indonesia, the Natural Resources Conservation Center (BKSDA), and the Government of Luwu Timur of Sulawesi. We thank Tri Widiyanto and his staff from Research Center for Limnology, Indonesian Institute of Sciences (LIPI) for 
their administrative support in obtaining the Scientific Research Permit. Special thanks are due to Jenny Wendt and Xavier Prieto for their assistance during methane analysis. Jan Axel Kitte is acknowledged for his support in the field and in the laboratory.

\section{Author contribution}

AF, SAC, JK designed the study and wrote the manuscript; AF, KB, CG, LO, VBH, AV, SN, RS performed experiments; $\mathrm{HV}, \mathrm{JMR}, \mathrm{CH}, \mathrm{SB}$ organized and managed the field campaign; HV, JMR, DA, DW, MM contributed to the writing of the manuscript.

\section{Members of the Towuti Drilling Project Science Team}

James M. Russell, Satria Bijaksana, Hendrik Vogel, Martin Melles, Daniel Ariztegui, Kohen W. Bauer, Sean A. Crowe, Alan Deino, Silvia Fajar, André Friese, Doug Haffner, Abdul Hafidz, Ascelina Hasberg, Cynthia Henny, Imran, Sarah Ivory, Jens Kallmeyer, Christopher Kelly, John King, Kartika Kirana, Ristiyanti Marwoto, Marina Morlock, La Ode Ngkoimani, Sulung Nomosatryo, Anders Noren, Ryan O’Grady, Luis Ordonez, Thomas von Rintelen, La Ode Safiuddin, Rachel L. Simister, Janelle Stevenson, Gerald Tamuntuan, Aurèle Vuillemin, Ian Watkinson, Nigel Wattrus, Satrio Wicaksono, Thomas Wonik

\section{References}

1. Berner RA. Biogeochemical cycles of carbon and sulfur and their effect on atmospheric oxygen over phanerozoic time. Palaeogeography, Palaeoclimatology, Palaeoecology 75, 97-122 (1989).

2. Keil RG. Terrestrial influences on carbon burial at sea. Proceedings of the National Academy of Sciences 108, 9729-9730 (2011).

3. Jørgensen BB. Mineralization of organic matter in the sea bed-the role of sulphate reduction. Nature 296, 643-644 (1982).

4. Froelich PN, et al. Early oxidation of organic matter in pelagic sediments of the eastern equatorial Atlantic: suboxic diagenesis. Geochimica et Cosmochimica Acta 43, 1075-1090 (1979).

5. Knittel K, Boetius A. Anaerobic Oxidation of Methane: Progress with an Unknown Process. Annu Rev Microbiol 63, 311-334 (2009).

6. Hartnett HE, Keil RG, Hedges JI, Devol AH. Influence of oxygen exposure time on organic carbon preservation in continental margin sediments. Nature 391, 572-574 (1998). 
7. Crowe SA, et al. Sulfate was a trace constituent of Archean seawater. Science 346, 735-739 (2014).

8. Poulton SW, Canfield DE. Ferruginous conditions: a dominant feature of the ocean through Earth's history. Elements 7, 107-112 (2011).

9. Roden EE, Wetzel RG. Competition between Fe (III)-reducing and methanogenic bacteria for acetate in iron-rich freshwater sediments. Microbial Ecology 45, 252-258 (2003).

10. Roden EE. Diversion of electron flow from methanogenesis to crystalline Fe (III) oxide reduction in carbon-limited cultures of wetland sediment microorganisms. Appl Environ Microbiol 69, 5701-5706 (2003).

11. Fortney NW, et al. Microbial Fe(III) oxide reduction potential in Chocolate Pots hot spring, Yellowstone National Park. Geobiology 14, 255-275 (2016).

12. Percak-Dennett EM, Beard BL, Xu H, Konishi H, Johnson CM, Roden EE. Iron isotope fractionation during microbial dissimilatory iron oxide reduction in simulated Archaean seawater. Geobiology 9, 205-220 (2011).

13. Crowe SA, et al. The methane cycle in ferruginous Lake Matano. Geobiology 9, 61-78 (2011).

14. Vuillemin A, et al. Geomicrobiological features of ferruginous sediments from Lake Towuti, Indonesia. Frontiers in Microbiology 7, (2016).

15. Crowe SA, et al. Photoferrotrophs thrive in an Archean Ocean analogue. Proceedings of the National Academy of Sciences of the United States of America 105, 1593815943 (2008).

16. Sheppard RY, et al. Characterization of Iron in Lake Towuti sediment. Chemical Geology 512, 11-30 (2019).

17. Russell JM, et al. The Towuti Drilling Project: paleoenvironments, biological evolution, and geomicrobiology of a tropical Pacific lake. Scientific Drilling 21, 29-40 (2016).

18. Costa KM, Russell JM, Vogel H, Bijaksana S. Hydrological connectivity and mixing of Lake Towuti, Indonesia in response to paleoclimatic changes over the last 60,000 years. Palaeogeography, Palaeoclimatology, Palaeoecology 417, 467-475 (2015).

19. Russell JM, et al. Glacial forcing of central Indonesian hydroclimate since 60,000 y BP. Proceedings of the National Academy of Sciences of the United States of America 111, 5100-5105 (2014).

20. Lovley DR, Phillips EJ. Organic matter mineralization with reduction of ferric iron in anaerobic sediments. Appl Environ Microbiol 51, 683-689 (1986).

21. Vuillemin A, et al. Formation of diagenetic siderite in modern ferruginous sediments. Geology 47 540-544 (2019). 
22. Canfield DE. The geochemistry of river particulates from the continental USA: Major elements. Geochimica et Cosmochimica Acta 61, 3349-3365 (1997).

23. Lovley DR, Phillips EJ. Availability of ferric iron for microbial reduction in bottom sediments of the freshwater tidal Potomac River. Applied and Environmental Microbiology 52, 751-757 (1986).

24. Poulton SW, Canfield DE. Development of a Sequential Extraction Procedure for Iron: Implications for Iron Partitioning in Continentally Derived Particulates. Chemical Geology 214, 209-221 (2005).

25. Zegeye A, et al. Green rust formation controls nutrient availability in a ferruginous water column. Geology 40, 599-602 (2012).

26. Crowe SA, Roberts JA, Weisener CG, Fowle DA. Alteration of iron-rich lacustrine sediments by dissimilatory iron-reducing bacteria. Geobiology 5, 63-73 (2007).

27. Canfield DE, Raiswell R, Bottrell S. The reacivity of sedimentary iron minerals towards sulfide. Am J Sci 292, 659-683 (1992).

28. Canfield DE, Thamdrup B, Hansen JW. The anaerobic degradation of organic matter in Danish coastal sediments: Iron reduction, manganese reduction, and sulfate reduction. Geochimica et Cosmochimica Acta 57, 3867-3883 (1993).

29. Whiticar MJ. Carbon and hydrogen isotope systematics of bacterial formation and oxidation of methane. Chemical Geology 161, 291-314 (1999).

30. Schwertmann U, Cambier P, Murad E. Properties of Goethites of varying crystallinity. Clays and Clay Minerals 33, 369-378 (1985).

31. Royer RA, Dempsey BA, Jeon BH, Burgos WD. Inhibition of biological reductive dissolution of hematite by ferrous iron. Environmental Science \& Technology 38, 187193 (2004).

32. Urrutia MM, Roden EE, Zachara JM. Influence of aqueous and solid-phase Fe(II) complexants on microbial reduction of crystalline iron(III) oxides. Environmental Science \& Technology 33, 4022-4028 (1999).

33. Raghoebarsing AA, et al. A microbial consortium couples anaerobic methane oxidation to denitrification. Nature 440, 918-921 (2006).

34. Deutzmann JS, Schink B. Anaerobic oxidation of methane in sediments of Lake Constance, an oligotrophic freshwater lake. Applied and environmental microbiology 77, 4429-4436 (2011).

35. Sivan O, et al. Geochemical evidence for iron-mediated anaerobic oxidation of methane. Limnology and Oceanography 56, 1536-1544 (2011). 
36. Beulig F, Røy H, McGlynn SE, Jørgensen BB. Cryptic CH4 cycling in the sulfatemethane transition of marine sediments apparently mediated by ANME-1 archaea. The ISME Journal 13, 250-262 (2019).

37. Vuillemin A, et al. Metabolic potential of microbial communities from ferruginous sediments. Environmental Microbiology 20, 4297-4313 (2018).

38. Holmkvist L, Ferdelman TG, Jørgensen BB. A cryptic sulfur cycle driven by iron in the methane zone of marine sediment (Aarhus Bay, Denmark). Geochimica Et Cosmochimica Acta 75, 3581-3599 (2011).

39. Roden EE. Fe(III) Oxide Reactivity Toward Biological versus Chemical Reduction. Environmental Science \& Technology 37, 1319-1324 (2003).

40. Jones AM, Collins RN, Rose J, Waite TD. The effect of silica and natural organic matter on the $\mathrm{Fe}(\mathrm{II})$-catalysed transformation and reactivity of $\mathrm{Fe}(\mathrm{III})$ minerals. Geochimica et Cosmochimica Acta 73, 4409-4422 (2009).

41. Jones C, Nomosatryo S, Crowe SA, Bjerrum CJ, Canfield DE. Iron oxides, divalent cations, silica, and the early earth phosphorus crisis. Geology 43, 135-138 (2015).

42. Canfield DE. The early history of atmospheric oxygen: Homage to Robert M. Garrels. Annual Review of Earth and Planetary Sciences 33, 1-36 (2005).

43. Laakso TA, Schrag DP. A small marine biosphere in the Proterozoic. Geobiology 17, 161-171 (2019).

44. Canfield DE, Rosing MT, Bjerrum C. Early anaerobic metabolisms. Philosophical transactions of the Royal Society of London Series B, Biological sciences 361, 18191836 (2006).

45. Katsev S, Crowe SA. Organic carbon burial efficiencies in sediments: The power law of mineralization revisited. Geology 43, 607-610 (2015).

46. Hedges JI, Keil RG. Sedimentary organic matter preservation: an assessment and speculative synthesis. Marine Chemistry 49, 137-139 (1995).

47. Vargas M, Kashefi K, Blunt-Harris EL, Lovley DR. Microbiological evidence for Fe(III) reduction on early Earth. Nature 395, 65-67 (1998).

48. Ueno Y, Yamada K, Yoshida N, Maruyama S, Isozaki Y. Evidence from fluid inclusions for microbial methanogenesis in the early Archaean era. Nature 440, 516519 (2006).

49. Thompson KJ, et al. Photoferrotrophy, deposition of banded iron formations, and methane production in Archean oceans. Science Advances 5, eaav2869 (2019).

50. Klein C. Some Precambrian banded iron-formations (BIFs) from around the world: Their age, geologic setting, mineralogy, metamorphism, geochemistry, and origins. American Mineralogist 90, 1473-1499 (2005). 
51. Fischer WW, Knoll AH. An iron shuttle for deepwater silica in Late Archean and early Paleoproterozoic iron formation. GSA Bulletin 121, 222-235 (2009).

52. Zheng X-Y, Beard BL, Reddy TR, Roden EE, Johnson CM. Abiologic silicon isotope fractionation between aqueous $\mathrm{Si}$ and $\mathrm{Fe}(\mathrm{III})-\mathrm{Si}$ gel in simulated Archean seawater: Implications for $\mathrm{Si}$ isotope records in Precambrian sedimentary rocks. Geochimica et Cosmochimica Acta 187, 102-122 (2016).

53. Ozaki K, Tajika E, Hong PK, Nakagawa Y, Reinhard CT. Effects of primitive photosynthesis on Earth's early climate system. Nature Geoscience 11, 55 (2018).

54. Friese A, et al. A simple and inexpensive technique for assessing contamination during drilling operations. Limnology and Oceanography: Methods 15, 200-211 (2017).

55. Viollier E, Inglett PW, Hunter K, Roychoudhury AN, Van Cappellen P. The ferrozine method revisited: $\mathrm{Fe}(\mathrm{II}) / \mathrm{Fe}(\mathrm{III})$ determination in natural waters. Applied Geochemistry 15, 785-790 (2000).

56. Murphy J, Riley JP. A modified single solution method for the determination of phosphate in natural waters. Analytica Chimica Acta 27, 31-36 (1962).

57. Glombitza C, Pedersen J, Røy H, Jørgensen BB. Direct analysis of volatile fatty acids in marine sediment porewater by two-dimensional ion chromatography-mass spectrometry. Limnology and Oceanography: Methods 12, 455-468 (2014).

58. Thamdrup B, Fossing H, Jørgensen BB. Manganese, iron and sulfur cycling in a coastal marine sediment, Aarhus Bay, Denmark. Geochimica Et Cosmochimica Acta 58, 5115-5129 (1994).

59. Jørgensen BB. A Comparison of Methods for the Quantification of Bacterial Sulfate Reduction in Coastal Marine Sediments 1. Measurement with radiotracer techniques. Geomicrobiol J 1, 11-27 (1978).

60. Fossing H. $35 \mathrm{~S}$-Radiolabeling to probe biogeochemical cycling of sulfur. In: Geochemical Transformations of Sedimentary Sulfur (eds Vairavamurthy MA, Schoonen MAA). American Chemical Society (1995).

61. Kallmeyer J, Ferdelman TG, Weber A, Fossing H, Jørgensen BB. A cold chromium distillation procedure for radiolabeled sulfide applied to sulfate reduction measurements. Limnology and Oceanography: Methods 2, 171-180 (2004).

62. Wang G, Spivack AJ, Rutherford S, Manor U, D'Hondt S. Quantification of cooccurring reaction rates in deep subseafloor sediments. Geochimica et Cosmochimica Acta 72, 3479-3488 (2008). 


\section{Supplementary Information}

\section{Iron oxide reactivity controls organic matter mineralization in ferruginous sediments}

André Friese, Kohen Bauer, Clemens Glombitza, Luis Ordoñez, Daniel Ariztegui, Verena B. Heuer, Aurèle Vuillemin, Cynthia Henny, Sulung Nomosatryo, Rachel Simister, Dirk Wagner, Satria Bijaksana, Hendrik Vogel, Martin Melles, James M. Russell, Sean A. Crowe*, Jens Kallmeyer*, and the Towuti Drilling Project Science Team

*Correspondence: jens.kallmeyer@gfz-potsdam.de, sean.crowe@ubc.ca

\section{Materials and Methods}

Pore water sampling and analysis

Whole round cores (WRC, $100 \mathrm{~mm}$ long x $66 \mathrm{~mm}$ diameter) were cut from the recovered sediment drill core, immediately capped and transferred into a $\mathrm{N}_{2}$-filled anaerobic chamber that was set up on site. Sediment was transferred under $\mathrm{N}_{2}$ to an IODP-Style PTFEtitanium pore water extractor 63 and squeezed using a 22-ton hydraulic press (Carver Inc., Wabash, USA). Pore water samples were filtered through a sterile $0.2 \mu \mathrm{m}$ syringe filter and collected in a glass syringe that was pre-flushed with nitrogen. Dissolved Fe concentrations were analyzed on site whereas the remaining pore water samples were preserved for later analysis of dissolved cat- and anions as well as volatile fatty acids (VFAs).

Concentrations of major anions (i.e. $\mathrm{Cl}-, \mathrm{SO}_{42-}, \mathrm{NO}_{3-}, \mathrm{NO}_{2-}$ ) in the pore water were measured by suppressed ion chromatography using a SeQuant SAMS anion IC suppressor (EMD Millipore, Billerica, Massachusetts), a S5200 sample injector, a $3.0 \times 250$ mm LCA 14 column and a S3115 conductivity detector (all Sykam, Fürstenfeldbruck, Germany). The eluent was $5 \mathrm{mM} \mathrm{Na} 2 \mathrm{CO}_{3}$ with $20 \mathrm{mg} \mathrm{L-1} 4$-hydroxybenzonitrile and $0.2 \%$ methanol. Flow rate was set to $1 \mathrm{~mL}$ min- 1 and column oven temperature to $50^{\circ} \mathrm{C}$. For cations (i.e. $\mathrm{Na}_{+}, \mathrm{NH}_{4+}$, $\mathrm{K}_{+}, \mathrm{Mg}_{2+}, \mathrm{Ca} 2+$ ), the IC system consisted of a S5300 sample injector (Sykam), a $4.6 \times 200$ mm ReprosilCAT column (Dr. Maisch HPLC, Ammerbuch-Entringen, Germany) and a S3115 conductivity detector (Sykam). The eluent was $175 \mathrm{mg} \mathrm{L-1}$ 18-Crown-6 and $120 \mu \mathrm{L}$ methanesulfonic acid. Flow rate was set to $1.2 \mathrm{~mL}$ min-1 and column oven temperature to $30^{\circ} \mathrm{C}$. Detection and quantification limits were calculated based on signal-to-noise (S/N) ratios of 3 and 10, respectively. All samples were measured in triplicates and every ten injections a standard was measured to check for drift. Reproducibility was always better than 
$5 \%$ for each ion. Detection limits for the major an- and cations ranged between $1-4 \mu \mathrm{M}$ and $6-11 \mu \mathrm{M}$, respectively.

Pore water phosphate concentrations were below the detection limit of ion chromatography and were therefore measured by spectrophotometry 56 . We aliquoted $0.5 \mathrm{~mL}$ pore water to $1.5 \mathrm{~mL}$ disposable cuvettes (Brand Gmbh, Germany) and added $80 \mu \mathrm{L}$ color reagent consisting of ammonium molybdate containing absorbic acid and antimony. Absorbance was measured at $882 \mathrm{~nm}$ with a DR 3900 spectrophotometer (Hach, Düsseldorf, Germany). Detection limit of the method was $0.05 \mu \mathrm{M}$.

The $\mathrm{pH}$ was measured with a portable $\mathrm{pH}$ meter (Thermo Scientific Orion, Star A321) calibrated at $\mathrm{pH} \mathrm{4,} 7$ and 10, respectively. We homogenized $2 \mathrm{~mL}$ of sediment in $2 \mathrm{~mL}$ of deionized water and measured the supernatant after 2 min, according to EPA method 9045D 64. Alkalinity was measured via colorimetric titration on a sample of hydraulically squeezed pore water. Dissolved inorganic carbon (DIC) concentrations were calculated by solving the carbonate system using the $\mathrm{pH}$ and alkalinity profiles and borehole temperatures.

Concentrations of volatile fatty acids (VFAs) in the pore water were measured by 2dimensional ion chromatography mass spectrometry (2D IC-MS) 57. This technique allows analysis of the following VFAs: lactate, acetate, propionate, formate, butyrate, pyruvate, valerate 57. As the method was originally developed for marine pore water samples, some modifications were made, as described below, to account for the low salinity of the pore water of Lake Towuti. The instrument used for 2D IC-MS analysis was a Dionex ICS3000 coupled to a Surveyor MSQ Plus mass spectrometer (both Thermo Scientific). Briefly, in this method the first IC dimension is used to separate the VFAs from other inorganic ions. The VFAs are trapped on a concentrator column and subsequently separated in the second IC dimension. To account for the effect of low salinity, the retention time window of the eluent flow from the first column that is directed to the concentrator column was shifted by one minute to $3.5-8.5$ min as compared to the marine pore water analysis protocol 57. Prior to analysis, the samples were filtered through disposable Acrodisc ${ }^{\circledR} 13 \mathrm{~mm}$ IC syringe filters (pore size $0.2 \mu \mathrm{m}$ ) that were rinsed with $10 \mathrm{~mL}$ Milli-Q® ${ }_{\circledast}$ water (Ultrapure Type 1) directly before use. The first 0.5 $\mathrm{mL}$ of pore water after filtration was discarded while the second $0.5 \mathrm{~mL}$ was used for analysis. Quantification was achieved by a 3-point calibration with external standards containing a mixture of the analyzed VFAs at different concentrations (i.e. 200, 500 and 800 $\mu \mathrm{g} \mathrm{L-1)}$ prepared in Milli-Q ${ }_{\circledast}$ water. Blank runs of pure Milli-Q ${ }^{\circledR}$ water were used to correct the peak areas for the small background peaks deriving from accumulation of VFAs from the 
eluent in the trap column. Detection limits for the individual VFAs were all between 0.1 and $0.4 \mu \mathrm{M}$ (i.e. formate: $0.37 \mu \mathrm{M}$, acetate: $0.19 \mu \mathrm{M}$, propionate $0.13 \mu \mathrm{M}$, butyrate: $0.09 \mu \mathrm{M}$ ).

\section{Iron speciation}

Our extractions dissolved $>92 \%$ of the Fe from the PACS -2 international reference standard. All Fe concentration measurements were performed using a Flame Atomic Absorption Spectrophotometer (Flame AAS). Precision on triplicate measurements was $1.2 \%$ and our limit of detection was $1500 \mathrm{ug} \mathrm{g-1}(0.15 \mathrm{wt} \%$ or $\sim 10 \mu \mathrm{mol} \mathrm{cm}-3)$.

\section{TOC analysis}

The total organic carbon (TOC) was analyzed by Rock-Eval 6 pyrolysis (Vinci Technologies). In the pyrolysis step $\sim 60 \mathrm{mg}$ sediment were heated to $650^{\circ} \mathrm{C}$ in an inert atmosphere. This released free hydrocarbons that were measured by a flame ionization detector (FID). Thermal cracking of long chain carbon compounds and carbonates produced $\mathrm{CO}$ and $\mathrm{CO}_{2}$ that were measured simultaneously by an infrared-cell. The carbonate related peak could be accurately identified allowing the differentiation between mineral and organic carbon. In a second step the material was reheated to $850{ }^{\circ} \mathrm{C}$ to quantify the remaining refractory organic matter. TOC $(\%)$ was calculated according to 65.

\section{Methane concentrations and isotopic analysis}

For methane analysis, $2 \mathrm{~cm} 3$ of sediment was retrieved with a cutoff syringe immediately after core retrieval and transferred to a $20 \mathrm{~mL}$ crimp vial filled with saturated $\mathrm{NaCl}$ solution and stored at $4^{\circ} \mathrm{C}$ without any headspace. Before analysis, $3 \mathrm{~mL}$ Helium was introduced as a headspace to all samples followed by equilibration for at least 24 hours. Methane concentrations were determined by injecting $200 \mu \mathrm{L}$ of the He headspace into a Thermo Finnigan Trace gas chromatograph equipped with a flame ionization detector (Thermo Fisher Scientific). Helium was used as a carrier gas with a constant flow rate of 2 $\mathrm{mL}$ min-1 and the split ratio was set to 5 .

In the $12 \mathrm{~m}$ core we analyzed the isotopic composition of the pore water methane. $\delta{ }_{13} \mathrm{C}\left(\mathrm{CH}_{4}\right), \delta{ }_{13} \mathrm{C}\left(\mathrm{CO}_{2}\right)$ and $\delta \mathrm{D}\left(\mathrm{CH}_{4}\right)$ were determined by injecting He headspace to a continuous-flow isotope ratio mass spectrometer (Delta V Plus, Thermo Fisher Scientific) equipped with a Trace GC Ultra (Thermo Fisher Scientific). For $\delta_{13} \mathrm{C}\left(\mathrm{CH}_{4},\right)$ and $\delta{ }_{13} \mathrm{C}\left(\mathrm{CO}_{2}\right)$ injection volume was $200 \mu \mathrm{L}$. Flow rate of the carrier gas was $3 \mathrm{~mL}$ min-1 and the split ratio was set to 3. For $\delta \mathrm{D}\left(\mathrm{CH}_{4}\right) 400 \mu \mathrm{L}$ of He headspace was injected. Flow rate was $2 \mathrm{~mL}$ min-1 
and the split ratio was 5. Results are in $\delta$ notation: $\delta{ }_{13} \mathrm{C}=\left(\left[13 \mathrm{C} /{ }_{12} \mathrm{C}\right]\right.$ sample $/\left[13 \mathrm{C} /{ }_{12} \mathrm{C}\right]$ standard 1)*1000 \%o referenced against Vienna Pee Dee Belemnite (VPDB, 13/12C ratio 0.0112372 $\pm 0.0000090)$ and $\delta \mathrm{D}=\left(\left[2 \mathrm{H} / 1 \mathrm{H}_{\text {sample }}\right] /\left[2 \mathrm{H} / 1 \mathrm{H}_{\text {standard }}\right]-1\right) * 1000 \%$ referenced against Vienna Standard Mean Ocean water (VSMOW, 2/1H ratio $0.00015576 \pm 0.00000010$ ).

where $\varepsilon$ is the standard-independent isotope difference between the two components, expressed in \%o.

\section{Potential sulfate reduction rates}

All incubations were done in triplicate. The microbially produced TRIS (total reduced inorganic sulfur) species were separated from the remaining sample and the unreacted sulfate tracer using the cold chromium distillation of Kallmeyer et al. (2004) 61. We added $8 \mathrm{~mL} 6 \mathrm{~N}$ $\mathrm{HCl}, 16 \mathrm{~mL}$ of $1 \mathrm{M} \mathrm{CrCl}_{2}$ and $20 \mathrm{~mL}$ of dimethylformamide to the distillation flask. Prior to addition of the reagents a small amount of non-radioactive zinc sulfide suspension was added as a sulfide carrier to enhance recovery. The released $\mathrm{H}_{2} \mathrm{~S}$ was collected in a trap filled with 5 $\%$ zinc acetate solution where $\mathrm{H}_{2} \mathrm{~S}$ was precipitated as zinc sulfide. Fresh traps were used for each fraction. The zinc acetate solution was transferred to a scintillation vial, then $8 \mathrm{~mL}$ Ultima Gold Scintillation Cocktail (Perkin Elmer) was added and the mixture homogenized. The radioactivity of recovered sulfide was quantified using a Tri Carb 2500 TR liquid scintillation counter (Packard Instruments, Meriden, CT, USA). Potential sulfate reduction rates were quantified according to 59 with the following equation:

$$
S R R=\left[S O_{4}^{2-}\right] \times P_{S E D} \times \frac{a_{T R I S}}{a_{T O T}} \times \frac{1}{t} \times 1.06 \times 10^{6}
$$

where SRR is the sulfate reduction rate (pmol cm-3d-1); [SO $42-]$ the sulfate concentration in the pore water (mmol L-1) plus $0.01 \mathrm{mmol} \mathrm{L-1} \mathrm{non-radioactive} \mathrm{sulfate} \mathrm{that} \mathrm{was} \mathrm{added} \mathrm{to} \mathrm{the}$ radiotracer; PSED is the sediment porosity ( $\mathrm{mL}$ pore water $\mathrm{cm}-3$ sediment); aTRIS is the radioactivity of TRIS (counts per minute); атот is the total radioactivity used (counts per minute); 1.06 is the correlation factor for the expected isotopic fractionation 66 and 106 is the factor for the change of units from mmol cm-3 d-1 to pmol cm-3 d-1. During incubation, turnover of the injected radiotracer was always below $1 \%$ in all experiments. The depthintegrated potential sulfate reduction rate $(\mathrm{mmol} \mathrm{m}-2 \mathrm{yr}-1)$ was calculated as the sum of all measured mean potential sulfate reduction rates from 0 to $12 \mathrm{~m}$. The uncertainty of that rate is the sum of the respective standard deviations. 


\section{Geochemical modeling}

Net reaction rates of dissolved chemical species linked to select microbial metabolisms (i.e. $\mathrm{Fe}_{2+}, \mathrm{CH}_{4}, \mathrm{NH}_{4+}, \mathrm{VFAs}$ ) were calculated using the MATLAB script of Wang et al. (2008) 62, assuming that the pore water concentration profiles represent steady-state conditions. We used a measured porosity profile (Table S1), which the model requires to calculate the formation factor based on the empirical relationship $f=10.0196 \phi^{-1.8812}$. The model applied a 5-point Gaussian filter to the respective pore water concentration profile, formation factor and porosity. Diffusion coefficients of the respective compounds were obtained from the compilation of 67 and were corrected for in-situ temperature using a temperature profile that was obtained by downhole logging (Table S1). We used a constant sedimentation rate of 1.9 10-4 m yr-1 19 and a constant external flow advection velocity near the SWI. A minimum of three measured concentration data points was used to determine each reaction zone. The model quantifies uncertainties in the rate estimates by using a Monte Carlo technique 62 .

Results of modeled turnover rates in the upper $0.5 \mathrm{~m}$ should usually be treated with caution because processes other than molecular diffusion can affect the pore water concentration gradients near the SWI. For example, bioturbation and/or advective transport can enhance the exchange of solutes between sediment and the overlying water 68,69 , although we can preclude bioturbation in this particular case because of the anoxic bottom water.

Moreover, disturbances can be caused by the impact of the coring device, especially larger corers like we used for the $12 \mathrm{~m}$ core completely destroy the uppermost sediment layer. We thus retrieved a short core $(<0.4 \mathrm{~m})$ with a small gravity corer that recovers an undisturbed SWI. This way we could increase the sampling resolution in the uppermost sediment layers, especially for methane. Due to the very steep gradient and strong curvature we combined the concentration profiles of both cores and used them as a single input for the model. Additionally, we ran a separate model for the short gravity core (Fig. S4). Both models are in good agreement to each other.

Summing up all modeled mean reaction rates within the upper $12 \mathrm{~m}$ yielded the depthintegrated reaction for the studied depth interval ( $\mathrm{mmol} \mathrm{m}-2 \mathrm{yr}-1)$. The sum of the respective modeled standard deviations yielded the uncertainty of that rate.

Using the data from our sequential Fe-speciation extraction we calculated depthintegrated rates of microbial Fe reduction by combining sedimentation rates with changes in Fe speciation between depth intervals, assuming steady-state deposition. We focused on sediment intervals in which a decrease in the total Fe(III) pool could be matched to a 
corresponding increase in the total Fe(II) pool, recognizing that some $\mathrm{Fe}(\mathrm{II})$ can be lost to the overlying water column via diffusive transport.

\section{Potential methane production}

We performed incubation experiments with sediment samples from three different depths $(0.36 \mathrm{~m}, 1.95 \mathrm{~m}$ and $7.4 \mathrm{~m})$ to investigate the potential for methane production in Lake Towuti sediment. Using a sterile cutoff syringe, we retrieved sediment samples of $0.5 \mathrm{~cm} 3$ each from WRCs that were stored in nitrogen-filled aluminum foil bags at room temperature. The respective sediment sample was transferred into an autoclaved $5 \mathrm{~mL}$ glass crimp vial together with $1 \mathrm{~mL}$ of sulfate-depleted freshwater medium mimicking the pore water concentrations of Lake Towuti sediment (Table S2). Due to the low pore water sulfate concentrations, we substituted the regular sulfur-containing reducing agent (sodium sulfide) with titanium citrate with a final concentration of $1.6 \mathrm{mM}$ in the medium. To check for the potential of hydrogenotrophic methanogenesis, the butyl stoppered glass crimp vial was flushed with a mixture of $\mathrm{H}_{2} / \mathrm{CO}_{2}(80 / 20 \%)$. A second experiment was set up, in which acetate was added with a final concentration of $100 \mu \mathrm{M}$ in the medium and $\mathrm{N}_{2} / \mathrm{CO}_{2}(80 / 20 \%)$ in the headspace. For controls the respective sediment samples were mixed with medium (Table S2) and the headspace flushed with $\mathrm{N}_{2} / \mathrm{CO}_{2}(80 / 20 \%)$. Killed controls were not run. All sample handling was done in a nitrogen-filled anaerobic chamber. The vials were constantly shaken in the dark at $100 \mathrm{rpm}$ at a constant temperature of $28^{\circ} \mathrm{C}$. Methane production in the experiments was measured by gas chromatography (Agilent Technologies, CA, USA).

After 35 days of incubation, headspace methane concentrations in the hydrogenotrophic incubations reached 17, 5.9 and 2.8 vol. \% in sediment from 0.36, 2 and 7.4 m, respectively (Fig. S2a). Acetoclastic methane production showed the same depth trend, albeit at a lower rate, never exceeding methane concentrations of 3 vol. \% (Fig. S2b). This is in line with the distribution of methane production indicated by modeling pore water profiles and methane isotopic compositions (Fig. 3 \& 4). In unamended control experiments methane production could only be observed in the uppermost sample and did not reach more than 1 vol. \%, implying that rates of methane production are limited by $\mathrm{H}_{2}$ and acetate substrate supply rates. 
Solutions to photochemical models 70 run across a range of biospheric $\mathrm{CH}_{4}$ fluxes can be approximated by the following equation 53:

$$
f\left(\mathrm{CH}_{4}\right)=a \times f l u x_{C H 4}^{b}
$$

Where $f\left(\mathrm{CH}_{4}\right)$ is the atmospheric $\mathrm{CH}_{4}$ mixing ratio, $a\left(=1.474 \times 10_{-26)}\right.$ and $b(=2.0291)$ are tunable constants, and fluxcH4 is the biospheric $\mathrm{CH}_{4}$ flux (molecules $\mathrm{cm}_{-2} \mathrm{~s}-1$ ).

Table S1: Input parameters for geochemical modeling: Input parameters for modeling of net turnover rates after the MATLAB script of Wang et al. (2008).

\section{SEPARATE XLS FILE}

Table S2: Medium composition for potential methane production experiments: Medium composition for incubation of methanogens in Lake Towuti sediment.

\section{Compound}

$\mathrm{MgCl}_{2} * 6 \mathrm{H}_{2} \mathrm{O}$

$\mathrm{CaCl}_{2} * 2 \mathrm{H}_{2} \mathrm{O}$

$\mathrm{NH}_{4} \mathrm{Cl}$

$\mathrm{K}_{2} \mathrm{HPO}_{4}$

$\mathrm{NaHCO}_{3}$

$\mathrm{FeCl}_{2} * 4 \mathrm{H}_{2} \mathrm{O}$

$\mathrm{CoCl}_{2} * 6 \mathrm{H}_{2} \mathrm{O}$

$\mathrm{MnCl}_{2} * 4 \mathrm{H}_{2} \mathrm{O}$

$\mathrm{ZnCl}_{2}$

$\mathrm{N}_{2} \mathrm{MoO}_{4} * 2 \mathrm{H}_{2} \mathrm{O}$

$\mathrm{NiCl}_{2} * 6 \mathrm{H}_{2} \mathrm{O}$

$\mathrm{H}_{3} \mathrm{BO}_{3}$

$\mathrm{CuCl}_{2} * 2 \mathrm{H}_{2} \mathrm{O}$

4-Aminobenzoate

Nicotinic acid

Ca-Pantothenate

Pyridoxine-Hydrochloride B6

Riboflavin

\section{Concentration (mg L-1)}

54

16

5

1.7

500

7.50

0.95

0.50

0.35

0.18

0.12

0.03

0.01

0.1

0.1

0.1

0.1

0.1 


$\begin{array}{ll}\text { Thyamine-Hydrochloride } & 0.1 \\ \text { Biotin } & 0.05 \\ \text { Folic acid } & 0.05 \\ \text { Lipoic acid } & 0.05 \\ \text { Vitamine B12 } & 0.05 \\ \text { Titanium citrate } & 237 \\ \text { Na-Resazurine } & 0.5\end{array}$

Table S3: Saturation indices modeled with PHREEQC v.3 based on $\mathrm{pH}$, alkalinity, pore water concentrations of major ions and borehole temperatures (modified after Vuillemin et al., 2019) ref 67

\section{$5 \mathrm{~m}$ : zone 1 Saturation $10 \mathrm{~m}$ : zone $\quad$ Saturation $35 \mathrm{~m}$ : zone $\quad$ Saturation}

2

4

\begin{tabular}{|lc|cc|cc|}
\hline talc & 1.43 & siderite & $\mathbf{1 . 0 0}$ & siderite & $\mathbf{1 . 0 0}$ \\
siderite & $\mathbf{1 . 2 9}$ & quartz & 0.71 & quartz & 0.71 \\
quartz & 0.71 & chalcedony & 0.29 & chalcedony & 0.29 \\
chalcedony & 0.29 & vivianite & $\mathbf{- 0 . 0 4}$ & vivianite & $\mathbf{- 0 . 0 4}$ \\
vivianite & $\mathbf{- 0 . 4 5}$ & talc & -0.31 & talc & -0.31 \\
$\alpha \mathrm{SiO}_{2}$ & -0.54 & $\alpha \mathrm{SiO}_{2}$ & -0.54 & $\alpha \mathrm{SiO}_{2}$ & -0.54 \\
calcite & -0.68 & calcite & -0.83 & calcite & -0.83 \\
dolomite & -0.77 & aragonite & -0.97 & aragonite & -0.97 \\
aragonite & -0.82 & dolomite & -1.27 & dolomite & -1.27 \\
\hline
\end{tabular}

Table S4: Compilation of turnover rates for reactants involved in organic matter mineralization. Rates were calculated for individual depth intervals, given as the mean rate as calculated by the model 52 and plus or minus one standard deviation.

SEPARATE XLS FILE

Figure S 1: Potential methane production experiments: Incubation experiments for potential hydrogenotrophic methanogenesis (A) and acetoclastic methanogenesis (B). Samples came from depths of $0.36 \mathrm{~m}, 1.95 \mathrm{~m}$ and $7.4 \mathrm{~m}$, indicated in pink, green and yellow, 
respectively. Circles are experiments with added substrate $\mathrm{H}_{2} / \mathrm{CO}_{2}(80 / 20 \%)$ in the headspace (A) or $100 \mu \mathrm{M}$ acetate in the medium (B). Triangles are negative controls with $\mathrm{N}_{2} / \mathrm{CO}_{2}$ $(80 / 20 \%)$ headspace. The negative controls were not amended with substrate, but not killed.
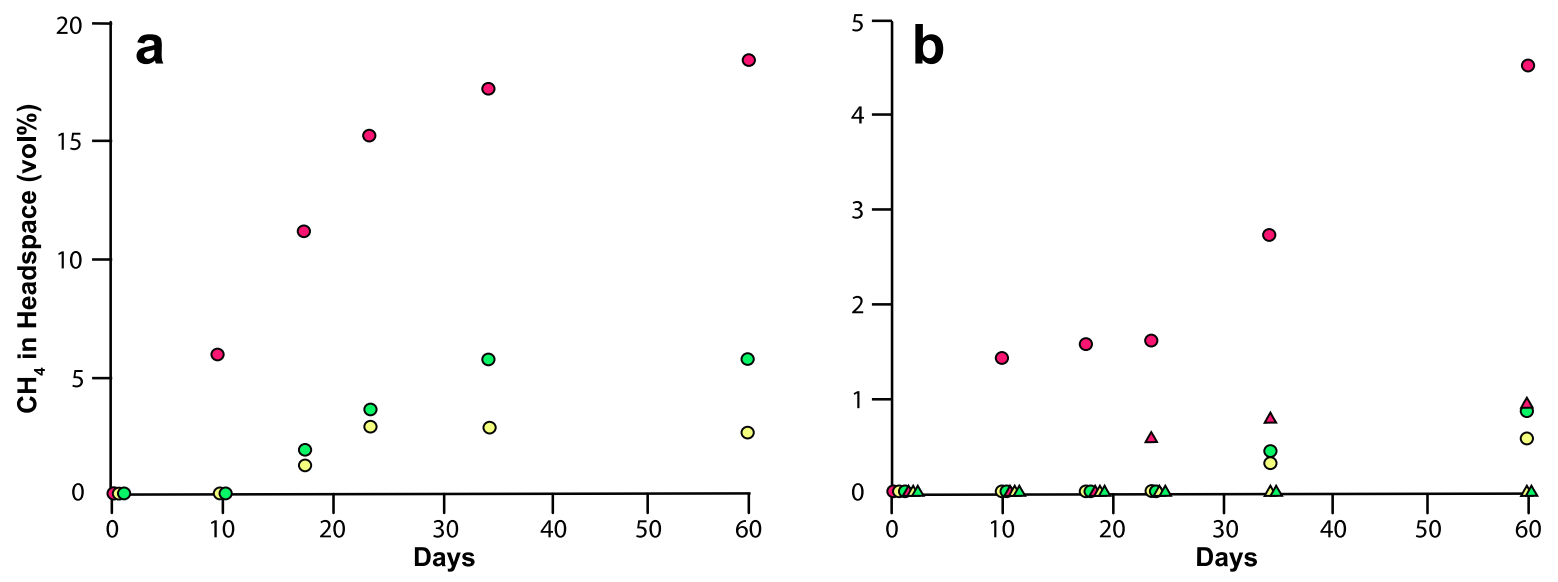

Figure S2: Geochemical modeling of pore water sulfate: Geochemical modeling of net turnover rates of pore water sulfate for the $12 \mathrm{~m}$ drill core. The modeled turnover rates are $10-160$ times lower than the measured potential sulfate reduction rates, which is consistent with previous observations on Lake Towuti sediments and similar environments $14,71,72$

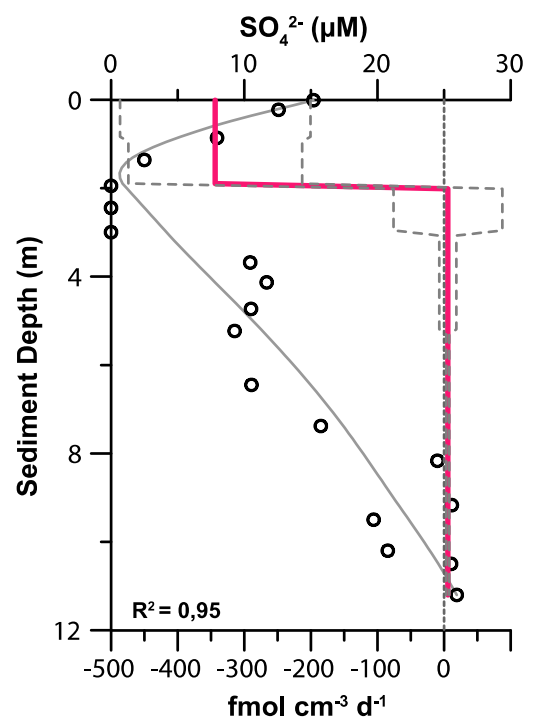

Figure S3: Geochemical modeling of pore water methane: Geochemical modeling of net turnover rates of pore water methane for the short core $(<0.4 \mathrm{~m})$ that was retrieved with a gravity coring device to better preserve the sediment water interface and thus to increase the accuracy of the modeling results. The net turnover rates show a good fit with those of our model in Figure 2 and even predict 
methane production rates up to $9 \mu \mathrm{mol} \mathrm{cm}-3 \mathrm{~d}_{-1}$ in the upper $3 \mathrm{~cm}$ of the sediment core yielding a depth integrated methane production rate of $162 \pm 19 \mathrm{mmol} \mathrm{m}-2 \mathrm{yr}-1$ for the upper $0.4 \mathrm{~m}$. Please note that the methane concentration in the uppermost sample $(0-0.5 \mathrm{~cm})$ is not zero but around $10 \mu \mathrm{M}$, indicating a net flux of methane out of the sediment.

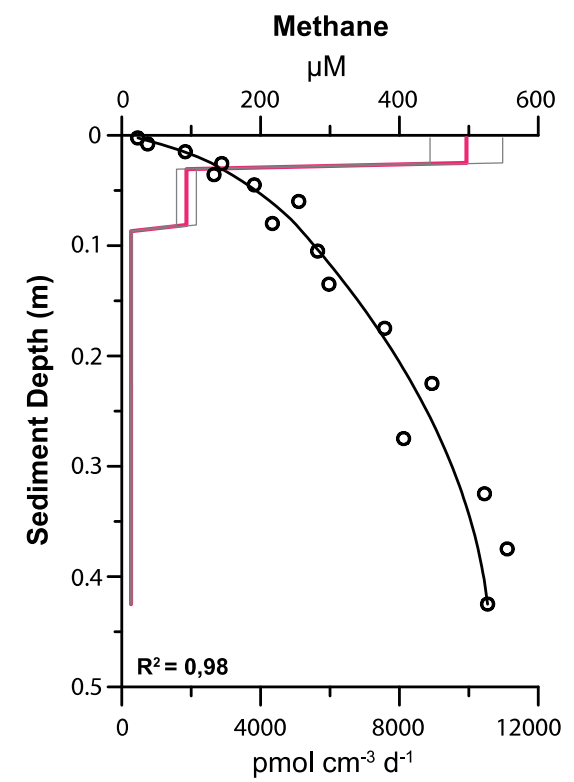

\section{References}

63. Manheim FT. A hydraulic squeezer for obtaining interstitial water from consolidated and unconsolidated sediments. USGS Reference Paper 550, 171-174 (1966).

64. EPA. Method 9045D, Soil and Waste pH.). EPA (2004).

65. Lafargue E, Marquis F, Pillot D. Rock-Eval 6 applications in hydrocarbon exploration, production, and soil contamination studies. Revue de l'institut français du pétrole $\mathbf{5 3}$, (1998).

66. Jørgensen BB, Fenchel T. The Sulfur Cycle of a Marine Sediment Model System. Marine Biology 24, 189-201 (1974).

67. Schulz HD. Quantification of Early Diagenesis: Dissolved Constitutents in Marine Pore Water. In: Marine Geochemistry (eds Schulz HD, Zabel M). Springer (2000).

68. Ziebis W, Forster S, Huettel M, Jorgensen BB. Complex burrows of the mud shrimp Callianassa truncata and their geochemical impact in the sea bed. Nature 382, 619-622 (1996).

69. Precht E, Huettel M. Rapid wave-driven advective pore water exchange in a permeable coastal sediment. Journal of Sea Research 51, 93-107 (2004).

70. Pavlov AA, Brown LL, Kasting JF. UV shielding of NH3 and $\mathrm{O} 2$ by organic hazes in the Archean atmosphere. Journal of Geophysical Research: Planets 106(E10), 2326723287 (2001). 
71. Norði KA, Thamdrup B, Schubert CJ. Anaerobic oxidation of methane in an iron-rich Danish freshwater lake sediment. Limnology and Oceanography 58, 546-554 (2013).

72. Urban N, Brezonik P, Baker L, Sherman L. Sulfate reduction and diffusion in sediments of Little Rock Lake, Wisconsi. Limnology and Oceanography 39, 797-815. 